Alex Mintz* and Uk Heo

\title{
Triads in International Relations: The Effect of Superpower Aid, Trade, and Arms Transfers on Conflict in the Middle East
}

\begin{abstract}
In this paper we extend dyadic research on conflict processes in international relations, to the analysis of triadic relationship. Specifically, we argue that although conflict can be explained at the dyadic level of analysis, a triadic analysis can greatly enrich our understanding of the dynamics of conflict and cooperation. We present a theory of triadic relationship and test it with data on the effect of aid and trade of Middle Eastern dyads with major powers (the US, The Soviet Union/Russia, the UK and France) in the post-WWII era using negative binomial regression. The results show the importance of expanding research in International Relations from dyadic to triadic interactions. Robustness tests demonstrate the validity of our analysis.
\end{abstract}

Keywords: triads, international relations, Middle East

\section{Introduction}

Studies of conflict and cooperation in international relations are primarily conducted at the dyadic level of analysis (Gartzke, Li, and Boehmer 2001; Kinsella and Russett 2002; Russett, Oneal, and Davis 1998). And indeed, Maoz et al. (2005) observe that there is a decline in popularity of systemic studies of international relations and of national-level studies of conflict, in favor of dyadic level research.

Several scholars (e.g. Gleditsch and Ward 2005; Maoz et al.2005) have recently begun focusing on the network as the level of analysis, essentially arguing that the network of relationships among N-members of the international community can explain conflict and cooperation in the international system. For example,

*Corresponding author: Alex Mintz, Dean, Lauder School of Government, Diplomacy and Strategy and Head of the Institute for Policy and Strategy (IPS) at the IDC, Israel, E-mail: mintz.alex@idc.ac.il

Uk Heo: Department of Political Science, University of Wisconsin-Milwaukee and Kyung Hee University, P.0.Box 413, Milwaukee, WI 53201, USA 
Maoz et al. (2005) examine characteristics like the density and polarization of international networks of ethnic similarity, alliances, and democratic states. They find that "alliance density in the system is associated with more militarized disputes and wars, and that democratic networks are associated with fewer disputes and wars" (Russett 2005). Gleditsch and Ward (2005) found that although conflict and democracy may not be related at the level of individual states, "once we look at the regional level and take into account where conflict is located, we find considerable overlap between areas where democracies cluster and regions where stable peace prevails.” (also see Vasquez 2009).

Zinnes and Muncaster (1997) have examined the network effect, defined as: "how each dyad relates to all other nations in the system... determined by the dyad's friendly and hostile relationships with every other nation." Schrodt and Mintz (1988) showed that conflictual and cooperative interactions between members of dyads often trigger interactions among other dyads. And indeed, the August 1990 invasion of Kuwait by Iraq (e.g. conflict directed from Iraq to Kuwait) had led to conflictual interactions between many other nations and Iraq.

A related, yet neglecter level of analysis in quantitative studies of International Relations is the triad (but see Goldstein and Freeman 1990; Goldstein and Pevehouse 1997; Goldstein et al. 2001; Lee, Muncaster, and Zinnes 1994; Schrodt 1978; Weede 1983). Triads consist of three members of the international community. For instance, countries A, B, and C; A, B and D, or A, B and E of which two of them may be linked through formal or informal alliance structures, while two may have a hostile relationship or one nation has influence on the other two nations. In this situation consisting of three nations, $\mathrm{A}, \mathrm{B}$, and $\mathrm{C}$, conflictual-cooperative relations between $\mathrm{A}$ and $\mathrm{B}$ are likely to be influenced by the behavior of country C, particularly when $\mathrm{C}$ is a super power, towards countries A and/or B. Aid, trade, and arms transfers are prime means of country C's actions towards countries A and/or B.

In this paper we employ a triadic analysis approach to extend existing dyadic research on conflict processes in international relations. Specifically, we argue that although conflict can be explained at the dyadic level of analysis, a triadic analysis can greatly enrich our understanding of the dynamic of conflict and cooperation, as dyadic behavior by itself is influenced by the behavior of third parties. For example, Lee, Muncaster, and Zinnes (1994) modeled and simulated the old rule that "the enemy of my enemy is my friend and the friend of my enemy is my enemy."

The relevance of our study to the "real world" can be illustrated with the following examples:

1. Since the Camp David accord of 1978 signed by then President Jimmy Carter, Egyptian President Anwar Saddat and Prime Minister of Israel, Menachem 
Begin, the US has supplied to both Israel and Egypt massive amounts of aid. Does US aid to both Egypt and Israel reduce the likelihood of this dyad being involved in militarized interstate disputes (MID)?

2. Does the fact that the US provides aid to both Jordan and Israel reduce the likelihood of these nations engage in militarized disputes?

3. With the US providing aid to Israel but Lebanon hardly receiving US aid, should we expect more or less conflict between Israel and Lebanon?

4. With the US providing aid to Israel and the Soviet Union/Russia supplying aid to Syria, is the Israel-Syria dyad more likely to be involved in militarized interstate disputes?

5. Does the fact that the US has provided aid to Israel but (until recent years) not to the Palestinians, has led to less dependence of the Palestinians on the US and consequently to less leverage of the US on the Palestinian Authority?

\section{Literature review and theory}

Previous studies investigating the effect of aid and/or trade dependence from the foreign policy compliance perspective have focused largely on the dyadic level. For example, Wittkopf (1973) studied the relationship between US aid and foreign policy compliance by correlating compliance data with aid data. By testing the correlation of the aid and compliance, the author attempted to determine whether US aid was used to induce, reward, or punish. His findings were largely inconclusive.

DeRouen and Heo (2004) tested whether US aid and military aid are correlated with foreign policy similarity with 76 developing countries in Asia, Middle East, Africa, and Latin America for 1946-1996 using Vector Autoregression. The authors found that aid was significantly associated with foreign policy compliance although used as a reward primarily rather than inducement. More specifically, they found a pattern that foreign policy similarity leads to greater economic aid for African countries, but greater military aid for Latin American states. They found no overarching patterns for countries in Asia and the Middle East.

In another study, Richardson and Kegley (1980) examined the relationship between export dependence and compliance using the dependent's voting agreement with the US in the UN from the previous year. They found a higher correlation between voting agreement of dependencies with the US than that of non-dependencies although compliance with the US was gradually decreasing since the 1960s.

The studies mentioned above examined the relationship between aid or trade and compliance in a dyadic context. In other words, the focus of previous 
studies was on whether economic aid from a supplier to a client state affects the client state's behavior. Thus, aid was hypothesized to influence the behavior of the client in a dyadic context. In this study, we extend dyadic analysis to triadic analysis while examining the effect of superpowers' aid, trade and arms transfer on dyadic conflictual behavior.

From the point of view of the client state, asymmetric dependence on a superpower may create vulnerability and lead to greater influence of the supplier on the recipients. Some triadic relationships result in asymmetric dependence of the client states on the superpower while in other cases the result is a symmetric dependence or no dependence at all. Asymmetric dependence on the third party results from one member of the dyad being heavily dependent on the superpower while the other is not. The United States-Israel-Lebanon is such an example. The US provides Israel with economic aid but does not supply aid to Lebanon. In contrast, as pointed out above, both Israel and Egypt receive large quantities of aid from the US relative to their national economies and are both highly dependent on this superpower, which is a situation of a symmetric dependence. As Iraq and Iran have not received US aid in the period under study, they were less dependent on the US.

\subsection{Triads theory}

Assuming three countries, A, B and C, there are different possibilities for interaction between country $\mathrm{C}$ and a dyad A-B. For example, country $\mathrm{C}$ can provide aid to both A and B, or it can supply aid to country A (only) but not to country B. ${ }^{1}$ These relationships can be stated as:

Aid from $C$ to $A$ and $B: C \rightarrow A, C \rightarrow B$;

Aid from $C$ to A but not from $C$ to $B: C \rightarrow A, C-/ /->B$;

Our main theoretical argument is that dyadic behavior, as manifested by involvement in militarized interstate disputes of countries A and B, is influenced by the relationship of members of the dyad with a third party (labeled as country $\mathrm{C}$, a superpower, in this study).

Our key point is that dyadic interactions hardly ever occur in isolation from the "outside world." Triadic relations are likely to influence dyadic behavior.

1 Country C can also provide aid to country A while Country D provides aid to country B, or it can be the case that country D supplied aid to Country B but was replaced by country C as the supplier of aid to country B. These permutations are beyond the scope of the current study. 
Specifically, third parties' actions may increase or decrease the likelihood of conflict among members of a dyad, particularly when a member (or both members) of the dyads is dependent on the third party through aid, trade, and/or arms transfers. The reason is that, according to Keohane (1965), "the more dependent a state is on a great power for trade, aid, or protection, the more responsive it is likely to be ... [because]... it is sufficient that the smaller state is aware that "Big Brother' is watching." Furthermore, economic aid may be necessary for the dependent countries "to pay for imports that they cannot afford solely on the basis of export earnings and capital transfers by direct foreign investment” (Richardson 1978, also see Bearce and Tirone 2010). Thus, the dominant country may be able to induce compliant behavior from the dependent state, such as not to use force or resort to arms. The ability of the dominant partner to punish non-compliant behavior by severing aid and/or trade is a leverage the dominant state has in inducing compliant behavior from the client nation (DeRouen and Heo 2004).

The rationale for our study can be found in the pliers analogy which means that a third party to the relations (e.g. a superpower) significantly influences the relations among members of the dyad using, for instance, economic aid supplied to both members of the dyads, thus exerting influence on reducing the number of militarized disputes in the dyad. Or it can increase the likelihood of militarized disputes for example, via arms transfers (Kinsella 1994, 2002).

Based on the pliers principle, the nature of the dependence relations in the triad can influence the frequency of conflict. We expect countries which are less dependent to be more likely to resort to conflict, while those who are in symmetric dependence to be the least likely. Countries in asymmetric relations are likely to resort to conflict but not as much as the independent dyads.

\subsection{Hypotheses}

In this study, we test the effect of superpowers' aid, trade (mainly imports of the client state from the super power for export dependence) and arms transfers to countries in the Middle East on dyadic conflict. We expect that:

1. Superpower aid to dyads in the Middle East will affect significantly dyadic conflict. Specifically:

1.1 Superpower aid to the larger recipient of aid in the dyad will reduce the number of Militarized Interstate Disputes (MID) in the dyad.

1.2 Superpower aid to the smaller recipient of aid in the dyad will not affect militarized disputes among members of the dyads.

2. Export dependence of client states in a dyad on a superpower will negatively affect the frequency of dyadic conflict. Specifically: 
2.1 Exports from larger exporter in the dyad to the superpower will negatively affect conflict among members of the dyad.

2.2 Exports from the smaller exporter in the dyad to the superpower will not significantly affect conflict among members of the dyads.

3. Arms transfers to dyads in the Middle East will lead to more dyadic conflict. Specifically:

3.1 Arms transfers from a superpower to the larger recipient of transfers in the dyad will lead to more disputes.

3.2 Arms transfers from a superpower to the smaller recipient of transfers in the dyad will positively affect the frequency of interstate dispute among members of the dyad.

The rationale for the differential effect of aid, trade and arms transfers on conflictual behavior of the dyads is that arms transfers are expected to increase the likelihood of conflicts (Kinsella 1994). Accordingly, we expect economic aid to reduce conflict while arms transfers to increase the probability of conflict among members of dyads. Exports from client states to a superpower should be negatively correlated with conflict as the client states depend on the superpower for markets (Caruso 2006; Oneal, Maoz, and Russett 1996; Oneal, Russett, and Berbaum 2003; Polachek 1980, 1999; Pollins 1989; Reuveny 2000).

\section{Research design}

\subsection{Geographical domain}

We focus on the Middle East, a region that has experienced relatively large number of militarized disputes in the post World War II era (Gledtitsch and Ward 2005) and receives varying levels of superpower aid (e.g. large quantities of aid from the US to such countries as Israel and Egypt, no US aid to Syria and Iran).

The following countries were included in our analysis: Egypt, Iran, Iraq, Israel, Jordan, Lebanon, Saudi Arabia, Syria and Turkey. These countries have participated actively in: a) the Israeli-Arab dispute (Israel, Syria, Egypt, Jordan, Lebanon), and b) in the Iraqi-Iranian conflict, and other disputes. Several states have exhibited cooperative behavior towards other members of this sub-system and this data is captured in the MIDs dataset. Specifically, the MIDs dataset shows that Egypt and Jordan, Lebanon and Jordan, Saudi Arabia and Egypt, Saudi Arabia and Jordan's relations were by and large cooperative and friendly (Maoz 2004). 
The suppliers of aid and arms exports in our study include the US, the UK, France and the Soviet Union/Russia. We included these superpowers because they are the permanent members of the UN Security Council. Since China has little interaction with these countries, China was excluded.

\subsection{Model specification}

To model triadic relations between superpowers and members of Middle Eastern dyads we have expanded the Oneal, Russett, and Berbaum (2003) formulation with the following modifications:

1. We have focused on the number (frequency) of dyadic Militarized Interstate Disputes (MIDs) as our dependent variable. In other words, we asked, whether triadic interactions influence the frequency of conflicts in dyads.

2. We have added to the Oneal, Russett, and Berbaum (2003) model independent variables that represent the smaller (and larger) volume of superpower aid/imports/arms transfers from the US, the Soviet Union/Russia, the UK, and France. This will allow us to distinguish whether aid, exports, and arms transfers influence dyadic conflict.

3. We have dropped geographical proximity and contiguity on the grounds that these are not important factors in conflict behavior of Middle East countries.

Our model is:

$$
\begin{aligned}
& \text { FREQUENCYMIDS }_{\mathrm{ij}, \mathrm{t}}=\alpha+\beta_{1} \text { TRADE }_{\mathrm{ij}, \mathrm{t}}+\beta_{2} \text { LESSDEM }_{\mathrm{ij}, \mathrm{t}}+\beta_{3} \text { GREATERDEM }_{\mathrm{ij}, \mathrm{t}}+ \\
& \beta_{4} \text { CAPRATIO }_{\mathrm{ij}, \mathrm{t}}+\beta_{5} \text { IGO }_{\mathrm{ij}, \mathrm{t}}+\beta_{6} \operatorname{ALLIES}_{\mathrm{ij}, \mathrm{t}}+\beta 7_{1} \text { GREATERAID }_{\mathrm{ij}, \mathrm{t}}+\beta_{8} \operatorname{LESSAID~}_{\mathrm{ij}, \mathrm{t}}+\mathrm{e}_{1, \mathrm{t}}
\end{aligned}
$$

Specifically, we model the number of militarized interstate disputes in a dyad (the dependent variable) as a function of the volume of trade between members of the dyads, joint IGO membership, the capability ratio, alliances, greater/less democracy, greater/lesser economic aid (and export dependence/arms transfer). ${ }^{2}$ With the exception of aid, arms transfer and exports, data on all of the variables in the model are commonly used in studies of conflict in the international system (Oneal, Russett, and Berbaum 2003; Russett and Oneal 2001).

All data are in 2001 constant dollars. Data on the number of Militarized Interstate Disputes (MIDs) were kindly provided by Zeev Maoz (2004). Data on all

2 See Oneal, Russett, and Berbaum (2003) for theoretical justification of this model specification. 
other variables except trade and arms transfers come from Oneal, Russett, and Berbaum (2003). Data on trade were taken from Gleditsch (2002). Data on arms transfers were from Brzoska and Ohlson (1987) and updated with various years of SIPRI Yearbook: Armaments, Disarmament and International Security.

\subsection{Variable definitions and data sources}

The description of the variables used in this study is below:

FREQUENCYMIDS=number of dyadic MIDS per year

TRADE $=$ total volume of trade in the dyad

LESSDEM=the lesser democratic member of the dyad based on the POLITY score

GREATERDEM=the greater democratic member of the dyad based on the POLITY sCore

CAPRATIO=the ratio of national capability index score of the dyad

IGO=joint membership of the dyad in IGO

ALLIES=formal alliance relationship with the superpower

GREATERAID=greater aid recipient in the dyad, as measured by the annual total amount of aid provided by the superpower

LESSAID=lesser aid recipient in the dyad, as measured by the annual total amount of aid provided by the superpower

Greater Aid and Lesser Aid are replaced in subsequent runs with Greater Exports, Lesser Exports, Greater Arms Transfer, and Lesser Arms Transfers.

Two types of data for aid and export dependence (super power's imports) can be used for the study: total amount and the amount normalized by the recipient's gross domestic product (GDP). We chose the former on the grounds that super power's aid increase will be perceived as an increase by the recipient government regardless of the size or growth of the recipient's economy. For instance, if the US increases its aid to Israel by five percent compared with the previous year, the Israeli government will appreciate the increase. However, if the Israeli economy grew five percent that year, normalizing by GDP will nullify the increase in the data set.

\subsection{Robustness tests}

We have conducted several robustness tests to validate our initial results. ${ }^{3}$ Specifically:

3 We ran the model with different measures of trade, such as total trade and import dependence. The results are insignificant. 
a) We ran the model with single equation estimates for each provider of aid (the US, UK, France, and Soviet Union/Russia) and as a pooled data of all providers combined.

b) We ran the model with the Israeli dyads and replicated the analysis while excluding the Israeli dyads. Both sets of runs are reported below. The rationale for excluding Israeli dyads from one set of runs was in order to examine the impact of regime type on conflict in the Middle East. Israel, as a democracy is "skewing" the results on interstate conflict in the region as it was involved during the period under study in several wars (the Six Day War of 1967, the War of Attrition of 1970, the Yom Kippur war of 1973, and the invasion of Lebanon in 1981-1985). Excluding Israel from one set of runs will also neutralize the pacifying effect of the Camp David accord on dyadic conflict between Israel and Egypt.

c) We ran the model without the Soviet Union/Russia's aid/imports/arms transfers and without Israel as a recipient to account for potential anomalies in the data.

\subsection{Unit of analysis and temporal domain}

Our unit of analysis is the dyad year. Our analysis covers the years 1960-2000, except for aid data from the Soviet Union/Russia to the members of dyads is shorter. The period of Soviet Union/Russia aid data available for Egypt, Iraq, Syria, and Turkey is 1975-1990. However, the period of Soviet Union/Russia aid data available for Iran (1975-1986) and Jordan (1977-1990) is shorter, and there is no data available for Israel, Lebanon, and Saudi Arabia.

\subsection{Estimation technique}

Since our dependent variable is event counts, a number of militarized interstate disputes during the given years, we have employed the negative binomial regression technique. Given that it is a panel data set, we have used negative binomial regression with random effects. Negative binomial regression is based on the Poisson distribution of the data common in event count data. Each count of event must be independent from each other in the sense that an occurrence of the event will not make another more or less likely, although the probability of each occurrence of the event may be related. The Poisson distribution assumes the equality of its mean and variance, although they are not common in real 
data. Most common phenomenon is that data have greater variance than the mean, commonly known as overdispersed. Negative Binomial regression is designed to deal with overdispersed Poisson data (Hilbe 2008).

\section{Results}

The results of all estimates of aid (single country estimates, pooled estimates, with and without Israel, and with and without Russia/the Soviet Union) show a very strong influence of third party's aid on dyadic interactions. Specifically, superpower's aid to members of the various dyads, significantly influenced conflict in the Middle East as measured by the frequency of militarized disputes. As can be seen in the tables below, the results are remarkably stable over different specifications and robustness tests. Aid from all providers except Russia/Soviet Union to the larger recipient in dyads in the Middle East reduces the likelihood of conflict among members of the dyads. This is a significant and robust finding with important policy and theoretical implications.

Specifically, Table 1 shows that greater aid from the US reduces the likelihood of militarized disputes among dyads in the Middle East. This finding is significant at the 0.01 level. Similarly, greater economic aid from the UK is associated with reduction in MIDs as is aid from France. These results are also significant at the 0.01 level and are robust in most of the different specifications (see below). Economic aid from the Soviet Union/Russia does not have a significant impact on conflict during the period of study. Turning to the results of estimates of economic aid on client states who receive lesser amount of aid in the dyad, the data show that the effect on these countries is insignificant.

The effect of control variables such as capability ratio and allies are rather robust across equations, but not total trade and joint membership in intergovernmental organizations (IGOs) in the dyad. Allies lead to less involvement in conflict in three equations. Specifically, alliance is statistically significant, and as expected negative, when we regress the effect of US, UK and French's aid to Middle Eastern countries. However, the effect is insignificant for Soviet/Russia aid. ${ }^{4}$ Capability ratio also reduces the number of MIDs in the Middle East in two equations (France and Russia/Soviet Union being the aid provider). In other words, the closer the capability ratio, the more the likelihood of conflict in the Middle East. The effect of joint membership in IGOs on dyadic conflict in the

4 Oneal, Russett, and Berbaum (2003) found a positive effect of allies on the onset of conflict. They explain that the interaction between allies could lead to conflicts of interest. 
Table 1: Negative binomial regression results of the effects of superpower aid on the frequency of conflict in the Middle East.

\begin{tabular}{lrrrr}
\hline Independent variable & US aid & UK aid & France aid & Russia aid \\
\hline Greater aid & -0.9996 & -0.9792 & -0.9895 & 0.0010 \\
& $(-2.67)^{\star \star}$ & $(-3.17)^{\star \star}$ & $(-2.72)^{\star \star}$ & $(0.18)$ \\
Less aid & -0.9995 & 1.0229 & -0.9865 & -0.9955 \\
& $(-1.22)$ & $(1.49)$ & $(-0.82)$ & $(-0.76)$ \\
Greater democracy & 1.0339 & 1.0533 & 1.0281 & 1.0423 \\
& $(1.23)$ & $(2.16)^{\star}$ & $(1.04)$ & $(0.83)$ \\
Less democracy & -0.9115 & 0.9271 & -0.9335 & -0.8206 \\
& $(-1.89)$ & $(-1.86)$ & $(-1.44)$ & $(-0.86)$ \\
Dyadic trade & 1.0001 & 1.0001 & 1.0001 & 1.0000 \\
& $(0.72)$ & $(0.72)$ & $(0.70)$ & $(0.30)$ \\
Allies & -0.3148 & -0.1887 & -0.3413 & -0.6600 \\
& $(-2.46)^{\star \star}$ & $(-3.04)^{\star \star}$ & $(-2.39)^{\star \star}$ & $(-0.41)$ \\
Joint memberships in IGOs & -0.9802 & -0.9491 & -0.9836 & 1.1239 \\
& $(-1.39)$ & $(-3.20)^{\star \star}$ & $(-1.06)$ & $(1.21)$ \\
Capability ratio (log) & -0.36848 & -0.7473 & -0.5996 & -0.2777 \\
& $(-1.53)$ & $(-1.53)$ & $(-2.19)^{\star}$ & $(-2.04)^{\star \star}$ \\
N & 1208 & 1208 & 1208 & 210 \\
Wald Ch & $38.30^{\star *}$ & $38.49^{\star \star}$ & $31.31^{\star \star}$ & 10.13 \\
\hline
\end{tabular}

*, **significant at $0.05,0.01$ level respectively, one-tailed tests; Figures in parentheses are t-statistic.

Middle East is negative and significant only in the UK case, but insignificant in other cases.

Contrary to our expectation, bilateral trade has no significant impact on conflict behavior. The results might have occurred due to the lack or relatively small amounts of bilateral trade in the region. Finally, examining the effect of "greater" democracy and "lesser" democracy of members of a dyad on the frequency of MIDs in the Middle East shows, in all the aid equations, that more democracy has no significant impact on conflict in this part of the world. Even if we exclude Israel from the data analysis, the results are the same.

Overall, the data analysis of individual suppliers of economic aid demonstrates a very strong and robust effect of economic aid from superpowers on the reduction of the frequency of conflict involvement in the Middle East. The control variables are mostly significant in the predicted direction.

Turning to the results of the pooled time series analysis for all suppliers of aid combined (see Table 2) one can see that only aid from the US has a significant effect on reducing militarized interstate disputes in the Middle East. These results are robust for the US regardless of the model specification. These results 
Table 2: Negative binomial regression results of the effect of superpower aid on conflict in the Middle East.

\begin{tabular}{|c|c|c|c|}
\hline Independent variable & All countries & Excluding Russia & Excluding Israel \\
\hline Greater US aid & $\begin{array}{l}-0.9984 \\
(-1.68)^{\star}\end{array}$ & $\begin{array}{l}-0.0003 \\
(-2.21)^{\star}\end{array}$ & $\begin{array}{l}-0.9984 \\
(-1.68)^{\star}\end{array}$ \\
\hline Less US aid & $\begin{array}{r}1.0036 \\
(0.34)\end{array}$ & $\begin{array}{r}0.0001 \\
(0.68)\end{array}$ & $\begin{array}{r}1.0036 \\
(0.56)\end{array}$ \\
\hline Greater UK aid & $\begin{array}{r}-0.9731 \\
(-1.15)\end{array}$ & $\begin{array}{c}-0.0171 \\
(-2.40)^{\star \star}\end{array}$ & $\begin{array}{r}-0.9731 \\
(-1.15)\end{array}$ \\
\hline Less UK aid & $\begin{array}{r}-0.9805 \\
(-0.26)\end{array}$ & $\begin{array}{r}0.0247 \\
(1.14)\end{array}$ & $\begin{array}{r}-0.9805 \\
(-0.26)\end{array}$ \\
\hline Greater France aid & $\begin{array}{r}0.0076 \\
(0.44)\end{array}$ & $\begin{array}{l}-0.0071 \\
(-2.01)^{\star}\end{array}$ & $\begin{array}{r}1.0076 \\
(0.44)\end{array}$ \\
\hline Less France aid & $\begin{array}{r}-0.9400 \\
(-0.97)\end{array}$ & $\begin{array}{r}-0.0025 \\
(-0.15)\end{array}$ & $\begin{array}{r}-0.9400 \\
(-0.97)\end{array}$ \\
\hline Greater Aid from Russia/Soviet Union & $\begin{array}{r}-0.9942 \\
(-0.86)\end{array}$ & & $\begin{array}{r}-0.9942 \\
(-0.86)\end{array}$ \\
\hline Less Aid from Russia/Soviet Union & $\begin{array}{r}-0.9952 \\
(-0.74)\end{array}$ & & $\begin{array}{r}-0.9952 \\
(-0.74)\end{array}$ \\
\hline Greater democracy & $\begin{array}{r}-0.9938 \\
(-0.13)\end{array}$ & $\begin{array}{r}0.0202 \\
(0.70)\end{array}$ & $\begin{array}{r}-0.9938 \\
(-0.13)\end{array}$ \\
\hline Less democracy & $\begin{array}{r}-0.7415 \\
(-1.35)\end{array}$ & $\begin{array}{l}-0.0864 \\
(-1.78)^{\star}\end{array}$ & $\begin{array}{r}-0.7415 \\
(-1.35)\end{array}$ \\
\hline Dyadic trade & $\begin{array}{r}-0.9999 \\
(-0.13)\end{array}$ & $\begin{array}{r}0.0001 \\
(0.43)\end{array}$ & $\begin{array}{r}-0.9999 \\
(-0.13)\end{array}$ \\
\hline Allies & $\begin{array}{r}-0.6748 \\
(-0.46)\end{array}$ & $\begin{array}{r}-1.2941 \\
(-2.64)^{\star \star \star}\end{array}$ & $\begin{array}{r}-0.6748 \\
(-0.46)\end{array}$ \\
\hline Joint memberships in IGOs & $\begin{array}{r}1.1186 \\
(1.23)\end{array}$ & $\begin{array}{r}-0.0178 \\
(-1.06)\end{array}$ & $\begin{array}{r}1.1186 \\
(1.23)\end{array}$ \\
\hline Capability ratio (log) & $\begin{array}{r}-1.667 \\
(-3.44)^{\star \star}\end{array}$ & $\begin{array}{l}-0.4256 \\
(-1.79)^{\star}\end{array}$ & $\begin{array}{c}-0.1667 \\
(-3.44)^{\star \star}\end{array}$ \\
\hline $\mathrm{N}$ & 210 & 1208 & 210 \\
\hline Wald $\mathrm{Ch}^{2}$ & $29.08^{\star \star}$ & $45.61^{\star \star}$ & $29.08^{\star \star}$ \\
\hline
\end{tabular}

*, **significant at 0.05, 0.01 level respectively, one-tailed tests; Figures in parentheses are t-statistic.

are important not only because they produce significant, robust results but also because they show that even when controlling for the effect of triadic relations between different superpowers and client states in a dyad, the results still hold. In other words, the inclusion of variables representing the UK, France and the Soviet Union/Russia has not changed the results of US aid on conflict behavior in the Middle East. Aid from the UK and France also reduce interstate disputes in the Middle East if we exclude Russia from the model. 
Overall, the data analysis of individual suppliers of economic aid demonstrates a very strong and robust effect of economic aid from superpowers except Russia/Soviet Union on the reduction of the frequency of conflict involvement in the Middle East. Most of the control variables are also significant in the predicted direction. A re-analysis of the data while excluding Israel dyads or aid from Russia/Soviet Union from the analysis generally reconfirmed the results.

We also tested the effect of trade (export dependence of the client state on super power) on conflict behavior. According to Polachek (1980), trade between pairs of states leads to mutual dependence. As a result, the cost of conflict between the states increases as the amount of trade enhances. Therefore, incentive for cooperation escalates as the trade amount between pairs of states increases (Polachek 1980). However, this argument is likely to hold when trade balance is more or less equal between the dyads. When one state is relying on another as to export, the other state is likely to have an influence, which is often the case in the relationship between superpowers and other client states (See Table 3).

Table 3: Negative binomial regression results of the effect of exports on the frequency of conflict in the Middle East.

\begin{tabular}{|c|c|c|c|c|}
\hline Independent variable & US & UK & France & Russia \\
\hline Greater export Dependence & $\begin{array}{c}-0.9998 \\
(-3.06)^{\star \star}\end{array}$ & $\begin{array}{c}-0.9995 \\
(-3.11)^{\star \star}\end{array}$ & $\begin{array}{r}-0.9999 \\
(-1.25)\end{array}$ & $\begin{array}{r}1.0006 \\
(3.12)^{\star \star}\end{array}$ \\
\hline Less export & 1.0001 & -0.9999 & 1.0000 & -0.9909 \\
\hline Dependence & $(1.06)$ & $(-0.15)$ & $(0.22)$ & $(-2.79)^{\star \star}$ \\
\hline Greater democracy & $\begin{array}{l}1.0525 \\
(2.16)^{\star}\end{array}$ & $\begin{array}{r}1.0324 \\
(1.46)\end{array}$ & $\begin{array}{r}1.0319 \\
(1.17)\end{array}$ & $\begin{array}{l}1.0541 \\
(2.19)^{\star}\end{array}$ \\
\hline Less democracy & $\begin{array}{r}-0.9433 \\
(-1.36)\end{array}$ & $\begin{array}{l}-0.9245 \\
(-1.75)^{\star}\end{array}$ & $\begin{array}{l}-0.9026 \\
(-2.12)^{\star}\end{array}$ & $\begin{array}{r}-0.9418 \\
(-1.44)\end{array}$ \\
\hline Dyadic trade & $\begin{array}{r}1.0001 \\
(0.72)\end{array}$ & $\begin{array}{r}1.0000 \\
(0.38)\end{array}$ & $\begin{array}{r}1.0001 \\
(0.86)\end{array}$ & $\begin{array}{r}1.0001 \\
(0.89)\end{array}$ \\
\hline Allies & $\begin{array}{c}-0.2568 \\
(-2.88)^{\star \star}\end{array}$ & $\begin{array}{l}-0.3411 \\
(-2.22)^{\star}\end{array}$ & $\begin{array}{l}-0.3783 \\
(-2.20)^{\star}\end{array}$ & $\begin{array}{l}-0.3502 \\
(-2.27)^{\star}\end{array}$ \\
\hline Joint memberships in IGOs & $\begin{array}{r}-0.9973 \\
(-0.16)\end{array}$ & $\begin{array}{r}-0.9788 \\
(-1.59)\end{array}$ & $\begin{array}{l}-0.9611 \\
(-2.93)^{\star \star}\end{array}$ & $\begin{array}{r}-0.9571 \\
(-2.87)^{\star \star}\end{array}$ \\
\hline Capability ratio (log) & $\begin{array}{l}-0.6751 \\
(-1.88)^{\star}\end{array}$ & $\begin{array}{l}-0.6826 \\
(-2.00)^{\star}\end{array}$ & $\begin{array}{l}-0.6395 \\
(-1.91)^{\star}\end{array}$ & $\begin{array}{l}-0.6819 \\
(-1.93)^{\star}\end{array}$ \\
\hline $\mathrm{N}$ & 1208 & 1208 & 1208 & 1208 \\
\hline Wald $\mathrm{Ch}^{2}$ & 33.6 ** & $33.6 * \star$ & $27.61^{\star \star}$ & $39.19^{\star \star}$ \\
\hline
\end{tabular}

*, ** significant at $0.05,0.01$ level respectively, one-tailed tests; Figures in parentheses are t-statistic. 
On the other hand, according to Pollins (1989), nations consider in their import decisions the political relationship with the country they import goods and services from in addition to the price and quality. Thus, importers seek to satisfy their security goals as well as economic ones, which imply that importers would choose exporters that they would be least influenced in terms of security although they may not have the same choice in terms of exporting their goods and services given the limited market. Thus, export dependence is more likely to have impact on conflict behavior than overall trade or import dependence and our results showed that. ${ }^{5}$

According to our empirical analysis (see Table 4), greater export dependence with the US and UK shows negative and significant effects on the frequency of conflict in the Middle East. However, export dependence with France has no significant effects and export dependence with Russia/Soviet Union shows a positive and significant effect on conflict. This result implies that the US and UK have leverage on Middle East countries with respect to resorting to arms. Given the amount of export to these countries, Middle East countries seemed to have listened to these superpowers.

The results also show an interesting pattern. The more export dependent on the US a county is, the fewer conflict the country gets involved. The Russia/Soviet Union case shows the exactly opposite pattern. Washington may pressure the country that is export-dependent on the US to avoid conflict. Apparently, countries that are export dependent on Russia/Soviet Union do not get the same pressure from Moscow.

The control variables, alliance, joint international organization membership, and capability ratio, have consistently shown, as expected, negative and significant effects on the number of conflicts in the region. Results of the pooled analysis with all of them together, excluding Russia/Soviet Union, or omitting Israeli dyads shows generally similar results although export dependence on France showed insignificant impact on conflict in the individual case analysis but in the pooled analysis export dependence on France leads to more conflict regardless of the level of dependence.

Finally, we tested the effect of arms transfers on the frequency of conflict. We hypothesized that greater arms transfer will lead to more conflicts. The results show that the more arms transfer from France leads to more conflict, but not the US and UK Arms transfer from Russia/Soviet Union showed no statistically significant impact. Less arms transfer from the US and France did reduce conflict in the

5 The empirical results of the impact of trade dependence and import dependence on the frequency of conflicts in the Middle East show no clear pattern. The use of other estimation methods and techniques did not produce robust findings. These results are available from the authors upon request. 
Table 4: Negative binomial regression results of the effect of export dependence on conflict in the Middle East.

\begin{tabular}{|c|c|c|c|}
\hline Independent variable & All countries & Excluding Russia & Excluding Israel \\
\hline Greater US export dependence & $\begin{array}{l}-0.9999 \\
(-1.88)^{\star}\end{array}$ & $\begin{array}{l}-0.0001 \\
(-2.47)^{\star \star}\end{array}$ & $\begin{array}{r}1.0000 \\
(0.25)\end{array}$ \\
\hline Less US export dependence & $\begin{array}{c}1.0002 \\
(2.46)^{\star \star}\end{array}$ & $\begin{array}{c}0.0002 \\
(2.61)^{\star *}\end{array}$ & $\begin{array}{r}1.0003 \\
(2.37)^{\star \star \star}\end{array}$ \\
\hline Greater UK export dependence & $\begin{array}{l}-0.9994 \\
(-2.95)^{\star \star}\end{array}$ & $\begin{array}{l}-0.0005 \\
(-2.85)^{\star \star}\end{array}$ & $\begin{array}{c}-0.9993 \\
(-2.66)^{\star \star}\end{array}$ \\
\hline Less UK export dependence & $\begin{array}{r}-0.9993 \\
(-1.41)\end{array}$ & $\begin{array}{r}-0.0006 \\
(-1.42)\end{array}$ & $\begin{array}{r}-0.9996 \\
(-0.68)\end{array}$ \\
\hline Greater France export dependence & $\begin{array}{l}1.0001 \\
(1.68)^{\star}\end{array}$ & $\begin{array}{r}0.0001 \\
(1.54)\end{array}$ & $\begin{array}{r}-0.9998 \\
(-0.94)\end{array}$ \\
\hline Less France export dependence & $\begin{array}{l}1.0004 \\
(1.71)^{\star}\end{array}$ & $\begin{array}{l}0.0005 \\
(1.89)^{\star}\end{array}$ & $\begin{array}{l}1.0005 \\
(1.82)^{\star}\end{array}$ \\
\hline Greater Russia/Soviet Union & 1.0005 & & 1.0012 \\
\hline Export dependence & $(2.60)^{\star \star}$ & & $(3.98)^{\star \star}$ \\
\hline Less Russia/Soviet Union & -0.9938 & & -0.9956 \\
\hline Export dependence & $(-2.43)^{\star \star}$ & & $(-1.97)^{\star}$ \\
\hline Greater democracy & $\begin{array}{l}1.0536 \\
(1.80)^{\star}\end{array}$ & $\begin{array}{r}0.0569 \\
(2.00)^{\star \star}\end{array}$ & $\begin{array}{r}1.0033 \\
(0.09)\end{array}$ \\
\hline Less democracy & $\begin{array}{r}-0.9263 \\
(-1.46)\end{array}$ & $\begin{array}{l}-0.0919 \\
(-1.75)^{\star}\end{array}$ & $\begin{array}{r}-0.9216 \\
(-0.70)\end{array}$ \\
\hline Dyadic trade & $\begin{array}{r}1.0000 \\
(0.43)\end{array}$ & $\begin{array}{r}0.0000 \\
(0.32)\end{array}$ & $\begin{array}{r}1.0001 \\
(0.64)\end{array}$ \\
\hline Allies & $\begin{array}{l}-0.4491 \\
(-1.76)^{\star}\end{array}$ & $\begin{array}{l}-0.8984 \\
(-2.01)^{*}\end{array}$ & $\begin{array}{r}-0.5561 \\
(-1.19)\end{array}$ \\
\hline Joint memberships in IGOs & $\begin{array}{l}-0.9726 \\
(-1.74)^{\star}\end{array}$ & $\begin{array}{r}-0.0198 \\
(-1.26)\end{array}$ & $\begin{array}{r}-0.9894 \\
(-0.53)\end{array}$ \\
\hline Capability ratio (log) & $\begin{array}{l}-0.6550 \\
(-1.75)^{\star}\end{array}$ & $\begin{array}{r}-0.3824 \\
(-1.61)\end{array}$ & $\begin{array}{l}-0.5142 \\
(-2.05)^{\star}\end{array}$ \\
\hline $\mathrm{N}$ & 1208 & 1208 & 931 \\
\hline Wald $\mathrm{Ch}^{2}$ & $58.49 * \star$ & $48.53^{\star \star}$ & $43.67^{\star \star}$ \\
\hline
\end{tabular}

${ }^{*},{ }^{* *},{ }^{* * *}$ significant at $0.1,0.05,0.01$ level respectively, one-tailed tests; Figures in parentheses are t-statistic.

Middle East. All control variables except bilateral trade amount, including alliances, joint international organization membership, and capability ratio, show significant relationship and in the direction predicted in the literature except capability ratio in the France equation.

Turning to the pooled analysis, the results are the same except the Russian case. The insignificant effect of Russian/Soviet Union arms transfer on conflict in the Middle East continues in the pooled analysis, but the effect becomes negative 
and significant in the pooled analysis excluding Israel. Control variables continue to show significant effects in the expected direction regardless of the model specification except bilateral trade amount (See Tables 5 and 6).

\section{Conclusion}

This paper tested the concept of triads in the study of international conflict. Our rationale for extending dyadic analysis to triadic analysis is that dyadic behavior typically does not occur in isolation. Instead, it is influenced by the behavior of third parties (superpowers) towards members of the dyad.

We showed that when a third party behavior is taken into account in the study of conflict, it has significant effect on dyadic behavior in numerous instances. Particularly, economic aid from the US, UK, and France significantly reduces the frequency of conflicts in the Middle East. The effects of export dependence and arms transfer seem to be less influential on conflict behavior compared with economic

Table 5: Negative binomial regression results of the effect of arms transfers on the frequency of conflict in the Middle East.

\begin{tabular}{lrrrr}
\hline Independent variable & US & UK & France & Russia \\
\hline Greater arms transfer & -0.9998 & 1.0000 & 1.0009 & 1.0001 \\
& $(-1.01)$ & $(0.03)$ & $(2.74)^{\star \star \star}$ & $(1.48)$ \\
Less arms transfer & -0.9983 & 1.0004 & -0.9922 & 1.0001 \\
& $(-2.60)^{\star \star}$ & $(0.96)$ & $(-1.96)^{\star}$ & $(0.29)$ \\
Greater democracy & 1.0322 & 1.0331 & 1.0301 & 1.0381 \\
& $(1.19)$ & $(1.21)$ & $(1.06)$ & $(1.39)$ \\
Less democracy & -0.8993 & -0.9077 & -0.9043 & -0.9156 \\
& $(-2.19)^{\star}$ & $(-1.99)^{\star}$ & $(-2.04)^{\star}$ & $(-1.82)^{\star}$ \\
Dyadic trade & 1.0001 & 1.0001 & 1.0000 & 1.0001 \\
& $(0.83)$ & $(0.68)$ & $(0.41)$ & $(0.68)$ \\
Allies & -0.3480 & -0.3915 & -0.3217 & -0.3839 \\
& $(-2.24)^{\star}$ & $(-2.12)^{\star}$ & $(-2.40)^{\star \star}$ & $(-2.18)^{\star}$ \\
Joint IGO membership & -0.9709 & -0.9592 & -0.9564 & -0.9568 \\
& $(-2.16)^{\star}$ & $(-3.12)^{\star \star}$ & $(-3.26)^{\star *}$ & $(-3.26)^{\star *}$ \\
Capability ratio (log) & -0.6680 & -0.6499 & -0.6926 & -0.6467 \\
& $(-1.71)^{\star}$ & $(-1.82)^{\star}$ & $(-1.55)$ & $(-1.87)^{\star}$ \\
N & 1208 & 1208 & 1208 & 1208 \\
Wald Ch & $33.74^{\star *}$ & $26.72^{\star *}$ & $34.34^{\star \star}$ & $27.99^{\star *}$ \\
\hline
\end{tabular}

*, ** significant at $0.05,0.01$ level respectively, one-tailed tests; Figures in parentheses are t-statistic. 
Table 6: Negative binomial regression results of the effect of arms transfers on conflict in the Middle East.

\begin{tabular}{|c|c|c|c|}
\hline Independent variable & All countries & Excluding Russia & Excluding Israel \\
\hline Greater US & -0.9999 & -0.0000 & -0.9997 \\
\hline Arms transfer & $(-0.57)$ & $(-0.56)$ & $(-1.18)$ \\
\hline Less US & -0.9983 & -0.0017 & -0.9859 \\
\hline Arms transfer & $(-2.56)^{\star \star}$ & $(2.65)^{\star \star}$ & $(-2.18)^{\star}$ \\
\hline Greater UK & 1.0002 & 0.0002 & 1.0004 \\
\hline Arms transfer & $(0.50)$ & $(0.51)$ & $(0.91)$ \\
\hline Less UK & 1.0024 & 0.0023 & 1.0045 \\
\hline Arms transfer & $(0.53)$ & $(0.50)$ & $(0.73)$ \\
\hline Greater France & 1.0009 & 0.0010 & 1.0009 \\
\hline Arms transfer & $(2.52)^{\star \star}$ & $(2.81)^{\star \star \star}$ & $(1.83)^{\star}$ \\
\hline Less France & -0.9937 & -0.0063 & -0.9963 \\
\hline Arms transfer & $(-1.63)$ & $(-1.63)$ & $(-1.02)$ \\
\hline Greater Russia/Soviet Union & 1.0000 & & -0.9996 \\
\hline Arms transfer & $(0.30)$ & & $(-2.00)^{\star}$ \\
\hline Less Russia/Soviet Union & -0.9999 & & 1.0002 \\
\hline Arms transfer & $(-0.08)$ & & $(0.47)$ \\
\hline Greater democracy & $\begin{array}{r}1.0337 \\
(1.18)\end{array}$ & $\begin{array}{r}0.0329 \\
(1.18)\end{array}$ & $\begin{array}{r}-0.9805 \\
(-0.65)\end{array}$ \\
\hline Less democracy & $\begin{array}{l}-0.9091 \\
(-1.91)^{\star}\end{array}$ & $\begin{array}{l}-0.0971 \\
(-1.97)^{\star}\end{array}$ & $\begin{array}{r}-0.8200 \\
(-1.61)\end{array}$ \\
\hline Dyadic trade & $\begin{array}{r}1.0000 \\
(0.33)\end{array}$ & $\begin{array}{r}0.0000 \\
(0.36)\end{array}$ & $\begin{array}{r}1.0000 \\
(0.27)\end{array}$ \\
\hline Allies & $\begin{array}{l}-0.3364 \\
(-2.20)^{\star}\end{array}$ & $\begin{array}{l}-1.0927 \\
(-2.21)^{\star}\end{array}$ & $\begin{array}{l}-0.4065 \\
(-1.67)^{\star}\end{array}$ \\
\hline Joint memberships in IGOs & $\begin{array}{l}-0.9683 \\
(-2.27)^{\star}\end{array}$ & $\begin{array}{l}-0.0321 \\
(-2.28)^{\star}\end{array}$ & $\begin{array}{r}1.0132 \\
(0.73)\end{array}$ \\
\hline Capability ratio (log) & $\begin{array}{r}-0.7089 \\
(-1.43)\end{array}$ & $\begin{array}{r}-0.3443 \\
(-1.44)\end{array}$ & $\begin{array}{l}-0.4572 \\
(-2.46)^{\star \star}\end{array}$ \\
\hline $\mathrm{N}$ & 1208 & 1208 & 931 \\
\hline Wald $\mathrm{Ch}^{2}$ & $43.63^{\star * *}$ & $43.39 * \star \star$ & $28.43^{* \star}$ \\
\hline
\end{tabular}

*, **significant at $0.05,0.01$ level respectively, one-tailed tests; Figures in parentheses are t-statistic.

aid. Control variables suggested in the literature, such as alliance, power capability ratio, and joint international organization membership consistently showed significant effects in the expected direction. However, bilateral trade amount has shown no statistically meaningful impact in the Middle East conflicts. The level of democracy also seems to be less relevant in this region (also see Henderson 2009 for the African case). 
These results are robust with respect to individual level and combined estimates, with and without Israeli dyads and subject to other robustness tests, such as including and excluding Russian aid/trade/arms transfer. Consequently, it is important to move the analyses of dyadic conflict in international relations to account for triadic and $\mathrm{N}$-adic behavior.

\section{References}

Bearce, David H., Tirone, Daniel C., (2010), Foreign Aid Effectiveness and the Strategic Goals of Donor Governments, Journal of Politics, vol. 72, no. 3, pp. 837-851.

Brzoska, M., Ohlson, T., (1987), Arms Transfers to the Third World 1971-85, Oxford University Press, Oxford.

Caruso R., (2006), A Trade Institution as a Peaceful Institution? A contribution to Integrative Theory, Conflict Management and Peace Science, vol. 23, no. 1, pp. 53-72.

DeRouen, Karl, Jr., Heo, U., (2004), Reward, Punishment or Inducement? US Economic and Military Aid, 1946-1996, Defense and Peace Economics, vol. 15, no. 5, pp. 453-470.

Gartzke, E., Li, Q., Boehmer, C., (2001), Investing in the Peace: Economic Interdependence and International Conflict, International Organization, vol. 55, no. 2, pp. 391-438.

Gleditsch, K., (2002), Expanded Trade and GDP Data, Journal of Conflict Resolution, vol. 46, no. 5, pp. 712-724.

Gleditsch, K. Skrede, Michael D. Ward. (2005), Visualization in the Study of International Relations, in Mintz, A., Russett, B., (eds.), New Directions in International Relations, Lexington Books, MA, Lexington, pp. 65-91.

Goldstein, Joshua S., Freeman, John S., (1990), Three-Way Street: Strategic Reciprocity in World Politics, University of Chicago Press, IL, Chicago.

Goldstein, Joshua S., Pevehouse, Jon C., (1997), Reciprocity, Bullying, and International Cooperation: Time-Series Analysis of the Bosnia Conflict, American Political Science Review, vol. 91, no. 3, pp. 515-529.

Goldstein, Joshua S., Pevehouse, Jon C., Gerner, Deborah J., Telhami, S., (2001), Reciprocity, Triangularity and Cooperation in the Middle East, 1979-97, Journal of Conflict Resolution, vol. 45, no. 5, pp. 594-620.

Henderson, E., (2009), Disturbing the Peace: African Warfare, Political Inversion and the Universality of the Democratic Peace Thesis, British Journal of Political Science, vol. 39, no. 1 , pp. 25-58.

Hilbe, Joseph M., (2008), Negative Binomial Regression, Cambridge University Press, New York.

Keohane, R., (1965), Political Influence in the General Assembly, Carnegie Endowment for International Peace, New York.

Kinsella, D., (1994), Conflict in Context: Arms Transfers and Third World Rivalry during the Cold War, American Journal of Political Science, vol. 38, no. 3, pp. 557-581.

Kinsella, D., (2002), Rivalry, Reaction, and Weapons Proliferation: A Time-Series Analysis of Global Arms, International Studies Quarterly, vol. 46, no. 2, pp. 209-230.

Kinsella, D., Russett, B., (2002), Conflict Emergence and Escalation in Interactive International Dyads, Journal of Politics, vol. 64, no. 4, pp. 1045-1068. 
Lee, S.C., Muncaster, R.G., Zinnes, D.A., (1994), The Friend of My Enemy Is My Enemy: Modeling Triadic International Relationships, Syntheses, vol. 100, no. 3, pp. 333-358.

Maoz, Z., (2004), The MID website. Accessed 2006 and 2008.

Maoz, Z., Terris, Lesley G., Kuperman, Rana D., Talmud, I., (2005), International Relations: A Network Approach, in Mintz, A, Russett, B., (eds.), New Directions for International Relations: Confronting the Method-of-Analysis Problem, Lexington Books, Oxford, pp. 35-64.

Oneal, John R., Maoz, Z., Russett, B., (1996), The Liberal Peace: Interdependence, Democracy, and International Conflict, 1950-85, Journal of Peace Research, vol. 33, no. 1, pp. 11-28.

Oneal, John R., Russett, B., Berbaum, Michael M., (2003), Causes of Peace: Democracy, Interdependence and International Organizations, 1885-1992, International Studies Quarterly, vol. 47, no. 3, pp. 371-393.

Polachek, S., (1980), Conflict and Trade, Journal of Conflict Resolution, vol. 24, no. 1, pp. 55-78.

Polachek, S.W. (1999), Conflict and Trade: An Economics Approach to Political International Interactions, Peace Economics, Peace Science and Public Policy, vol. 5, no. 2, pp. 1-32.

Pollins, B., (1989), Conflict, Cooperation, and Commerce: The Effect of International Political Interactions on Bilateral Trade Flows, American Journal of Political Science, vol. 33, no. 3, pp. 737-761.

Reuveny, R., (2000), The Trade and Conflict Debate: A Survey of Theory, Evidence and Future Research, Peace Economics, Peace Science and Public Policy, vol. 6, no. 1, pp. 1-29.

Richardson, N.R., (1978), Foreign Policy and Economic Dependence, University of Texas Press, Austin and London.

Richardson, N.R., Kegley, Charles W., (1980), Trade Dependence and Foreign Policy Compliance: A Longitudinal Analysis, International Studies Quarterly, vol. 24, no. 2, pp. 191-222.

Russett, B., (2005), Four Methods and Five Revolutions, in Mintz, A., Russett, B., (eds.), New Directions for International Relations: Confronting the Method-of-Analysis Problem, Lexington Books, Oxford, pp. 21-34.

Russett, B., Oneal, J., (2001), Triangulating Peace: Democracy, Interdependence and International Organizations, Norton, New York.

Russett, B., Oneal, J., Davis, D., (1998), The Third Leg of the Kantian Tripod for Peace: International Organizations and Militarized Disputes, International Organization, vol. 52, no. 3, pp. 441-467.

Schrodt, Philip A., (1978), Richardson's N-Nation Model and the Balance of Power, American Journal of Political Science, vol. 22. no. 2, pp. 364-390.

Schrodt, Philip A., Mintz, A., (1988), The Conditional Probability Analysis of International Events Data, American Journal of Political Science, vol. 32, no. 1, pp. 217-230.

Vasquez, J., (2009), The War Puzzle Revisited, Cambridge University Press, Cambridge.

Weede, E., (1983), Extended Deterrence by Superpower Alliance, Journal of Conflict Resolution, vol. 29, no. 2, pp. 231-254.

Wittkopf, E., (1973), Foreign aid and U.N. Votes: A Comparative Study, American Political Science Review, vol. 67, no. 3, pp. 868-888.

Zinnes, Dina A., Muncaster, Robert G., (1997), Prospect Theory versus Expected Utility Theory: A Dispute Sequence Appraisal, in Geva, N., Mintz, A., (eds.), Decisionmaking on War and Peace, The Cognitive-Rational Debate, Lynne Rienner Publishers, Boulder, pp. 183-211. 